\title{
アイソトープの常識
}

株式会社島津製作所レントゲン部

後藤義雄

\section{Introduction to Radioisotopes}

Yoshio Goto

X-ray Department of Shimazu Seisakusho Ltd., Kyoto.

第二次の世界大戦に於て，原子爆弾が出現してから 原子力に関する研究は, 日と共に盛えになり最早今日 の新聞距上に於ては，原子力に関する記事が見当らな い日が無い程, 我々の日常生活にとって最も関俰深い むのになってきました。

扱て我々医療器械を取报っているものにとって，原 子力の医療方面への応用特に原子爆弾の副産物である コバルト 60 等の人工放射性のアイントープが， 天然 の放射性同位元素であるラジウムやェックス線の深部 治療装置にとって代り普及しつ〉ある現状を見ます と、アイソトープ即ち，これ等放射性の同位元素に関 心を持つ事は最も必要な事であります。

それではアイイトープ即ち，日本語に訳して同位元 素とは一体なんであるかと申しますと，先ず元素や原 子がなんであるかという事から御説明申し上げなけれ ばなりをせん。

我々の周囲にあるあらゆる物質例总ば，空気でも水 でもこれをこまかく分けてゆくと，最早これ以上幾等 分割しても其の化学的性質が变らない窮極のものに達 します．この極限のものを我々は元素と称しておりま す，例えば水をこまかく分けてみますと，水という分 子が沢山集まって出来ており，更にこの水の分子をこ まかく分けると，最早水上は言われない水素と酸素と から出来ていることが解ります．この水素もこれ以上 分割しても 水素とか酸素とかの化学的性質が变りま せえからこれを元素と称しておりをす，これら元素は 軽いものは水素から重いものはウランに至る迄 100 余 種類あって 各ふが組合せられてあらゆる物質を形造 っております，それはあたかもイロ八 48 文字又はフ ルファベッド 26 文字が種々組合せられて数多くの言 葉が作られてるるうなるのであります。

更にこの元素を物理的構造から細分しますと，原子 といふ微粒子から出来ており, 従って元素は原子の集 りという事が出来ます，例えば水の場合ですと

第 1 図の如く水の分子は水素と酸素の元素から出来 ておりますが，いい換えれば2ヶの水素原子と 1 ヶの 酸素原子から出来てるものという事が出来ます，それ ではこの原子とはどういう構造であるがと申します

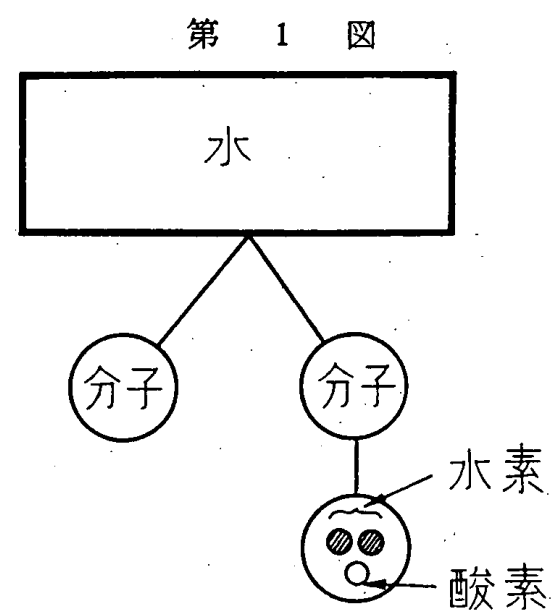

と，第2図(b)の如く陽子と中性子からなる原子核と， これをとりまく電子から出来て抢り,直径が大体 $10^{-8} \mathrm{~cm}$ 即ち一億分の一糎という非常に小さいもので，陽子 は(十)の電気を持つており質量は電子より遙かに重 く，電気的に中性である中性子と共に原子の質量の大 部分を占めております，一方電子は電気的に(ー)の電 荷と陽子の千八百四十分の一の質量を持っており, 原 子核の周囲をぐるぐる回転しております．電子の数は 原子核内の陽子の数之同数で, 即ち陽子の(+)の電気 と電子の(一)電気性釣合っておりますから，従って原 子全体としては電気的に中性を保っております，水で も空気でも皆かように釣合を保った原子から出来てお ります.

さて原子の陽子の数と中性子の数を加えたものを質 量数といって原子の重さを表わし; 又陽子の数を原子 番号といって原子の性質を表わしております，又陽子 の重さと中性子の重さは殆んど等しく $1.7 \times 10^{-24}$ グラ ムと言われております。

今一番簡単な水素原子を例にとって見ますと，第 2

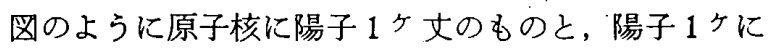
中性子1 学加光たものと, 更に又陽子 1 ケに中性子 2ヶ加えたすのと三種類あります。

この陽子 1 ケ丈のものは天然に最も多ぐ存在して所 謂水の水素核です. 又中性子 1 ケ丈のものは重水之称 する重い水で天然の水の中に若干含をれております。 更に陽子 1 ケに中性子 2 ケ加えたものは三重水素核と 
第 2 図

(a) ${ }_{1} \mathrm{H}^{1}$ (水素核)

(b) ${ }_{1} \mathrm{H}^{2}$ (重水素核)

(c) ${ }_{\mathrm{i}} \mathrm{H}^{3}$ (三重水素核)

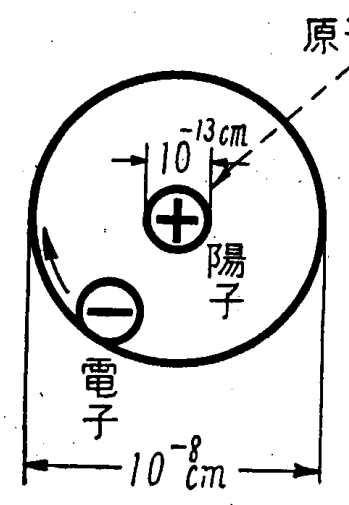

$Z=1 \quad A=1$

$\mathrm{Z}=$ 原子番号 =陽子数
原子核

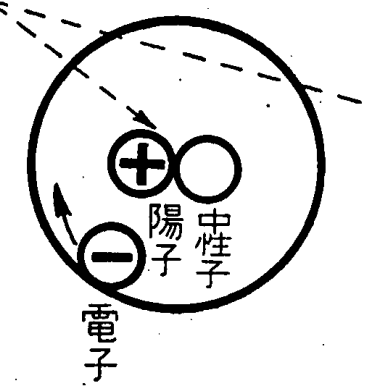

$Z=1 \quad A=2$

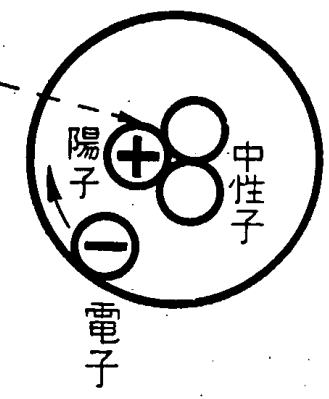

$Z=1 \quad A=3$
$A=$ 質量数 $=$ 陽子数 + 中性子数

陽子質量＋中性子質量 $\div 1.7 \times 10^{-24} \mathrm{gr}$,

事も可能ですし，一つの元素を 他の元素に变える事も可能なわ けです，それなら核変化をさせ る為にはどうしたら良いかと申 しますと，原子を構成してる電 子陽子中性子の結合を乱せば良 いのですから, 他からこれ等の むのを原子にぶつけてやれぼ良 いわけです：所が種々の実験結 果, 電子線や陽子線は原子の電 気と互ひに反発しあって近づき にくく，電気的に中性である中 性子線が容易に原子に近つき易 い事が解ったのです。ですから 人工的に原子核を破壊する為に

言われ，天然にも存在するが，原子炉でも製造され， 非常に不安定である為 $\boldsymbol{\beta}$ 線という放射線を出して，よ り安定な He（ヘリウム）の原子になりまず。

．以上のように水素原子には三種類もありますが; 陽 子の数は必ず 1 ケで，これが水素という原子の化学的 性質を决定しております，従って陽子の数が等しくて む中性子の数が異る原子核は；互いに化学的性質が同 じであっても物理学的性質が非常に異るものです，そ こでこのような原子核からなる元素を互ひに同位元素 と称しております。この同位元素には安定なものと， 不安定なものとあって，即ち三重水素核のように不安 定で $\boldsymbol{\beta}$ 線という放射線を出すものもあります.このよ うに放射線を出す同位元素を放射性の同位元素といひ ます，この放射性の同位元素の中にはラジウムのよう に天然に放射線を出すむのと，或は又コバルト60のよ うに人工的に原子炉等で作り出されるもと二通りあっ て，後者を人工放射性同位元素と呼んでおります，我 ↔が普通 "アイソトープ゙と称するものはこの人工放 射性同位元素, 即ちラジオ. アイソトーブを指すむの です.

一般に質量数，即亏陽子と中性子の多 い原子は水素やへリウムのように質量数 の少い原子に比べて陽子と電子の結合が 不安定で，原子核の变化によって放射線 を放出し常に安定した元素に变ろうとし ております，即ちウランとがラジウム は不安定な元素であって, 其の為, 天然 に放射線を出してょり安定な元素に変る ものです，それでは逆に原子から放射線 を出させる為には何等かの方法で，原子 を不安定にしてやれば良いのですから， 人工的にも原子から放射線を放出させる
は中性子を用ひます，即ち中性子は電気的に力を受け る事なく，エネルギーの低い，而も遅い中性子でも容 易に原子核近く迄入る事が出来ます。

例えば原子炉の燃料である ${ }_{82} \mathrm{U}^{239}$ (ウラン 235 一般 に原子記号の左下に原子番号右上に質量数を書く）の 如きものは $1 \mathrm{eV}$ (エレクトロンボルト) 以下の中性 子を当てると，原子核が分裂して，所謂核分裂の連鎖 反応を起します。こ」で1電子ボルトというのは，1 ボルトの電位差で電子を運動させた時に得るエネルギ 一の事で，放射線のエネルギー単位として用いられて おります。

${ }_{82} \mathrm{U}^{235}$ に 1 ケの中性子を当てると, 第 3 図の如く種 々な分裂の仕方をしますが，二つの中位の原子 ${ }_{42} \mathrm{Mo}^{95}$ (モリブデン) と， ${ }_{87} \mathrm{La}^{189}$ (ランタン) に分裂し，2ケ の中性子， $\boldsymbol{\beta}$ 線， $\gamma$ 線を放出します。乙の新しく出来 た中性子が別のウランの原子核に吸収されて，鼠算式 に中性子の数が増えこの反応を制御しないと、所謂原 子爆弾になるのです：そこで 1 回の核分裂に依的発生 した 2 ケの中性子の中常に 1 ケ丈を次の核分裂に使用 し，他の 1 ヶは黒鉛とか硼素等の減速材で吸収してや 第 3 図

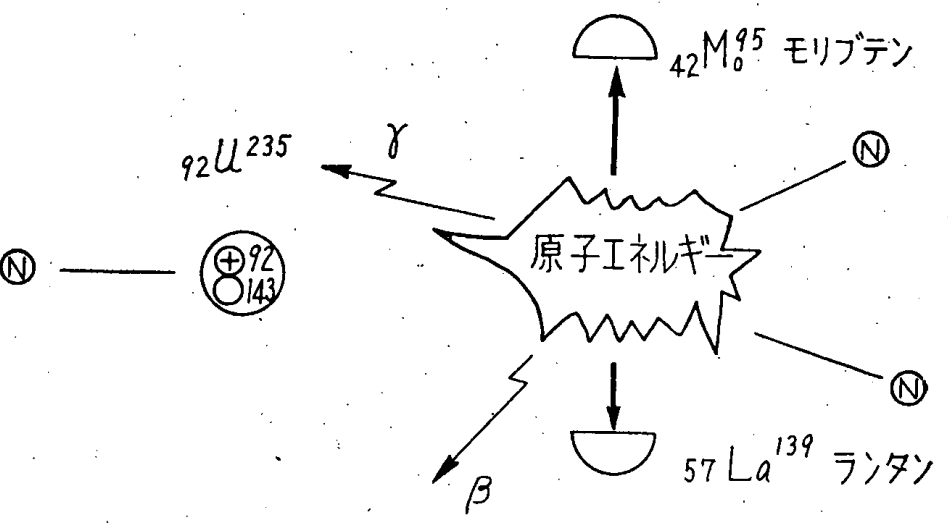


るようにすれば，一定の連鎖反応丈を繰返えし爆発し ないで済みます。これが原子悷の原理で， 1 瓦の ${ }_{92} \mathrm{U}^{235}$ の分裂で発生する其のエネルキ一は石炭約 3.3 トの 燃燒に匹敵すると言われておりますから，原子爆弾が 如何に莫大なエネルギーを持っているか想像に難くあ りません。

さて核分裂によって斯様に中性子が発生致しますの で，原子师の中では簡単に中性子が得られますから， 人工的に放射性元素も容易に作り得られるわけです。

例えばコバルト 60 の如き放射性の同位元素が どう して作られるかと申しますと，原鉱の ${ }_{27} \mathrm{Co}^{59}$ を採鉱 精鍊して原子炉の中に入れて中性子を与へると原子核 变化を起して，放射性同位元素の ${ }_{27} \mathrm{CO}^{80}$ になり，逐 次变化して $\boldsymbol{\beta}$ 線や $\dot{\gamma}$ 線を出してニッケルになります. 其の他アイントーブとして広く医療方面に用いられる 放射性の燐とか，ヨードも同様にして作られる比較的 軽い不安定な元素です。

このように核变化に依り簡単に放射性の同位元素を 製造する事が出来るようになりましたが，其の核変化 により放出される放射線には $\alpha, \beta, \gamma$ の三種類があ り、之等の放射線がぞのような性質を持っているかと 申しますと，先ず $\alpha$ 線とは ${ }_{2} \mathrm{He}^{4}$ (へリウム) の原子 核の粒子で陽子が 2 ケ，中性子が 2 ケの粒子線で，即 ち(十)の電気の粒子線です，従って強い電離作用を持 っており方すが透過力は弱く大体空気中で数粯迄で水 や生体ならば 1 粕内外で 1 枚の紙で阻止する事が出来 ます.こ〉で電離作用というのは先に原子の電子と陽 子は数が等しく電気的に釣合を保っていると申しまし たが：これらの数が等しくなくなり電気的に釣合を保 てなくなる事，即ち原子として負に带電したり正に带 電したりすることのような状態を電離又はイオン化と いっております。

次に $\beta$ 線とは (一) の電気をもった粒子線, 即ち電 子線で $\boldsymbol{\alpha}$ 線に比へて電離作用は弱いが透過力は $\alpha$ 線 より強く，空気中なら数十榞から 1 米位で，水中や生 体なら 2 糎以内で、数粍のフルミニュームで包めば外 えは飛び出しません。

最後の $\gamma$ 線は非常にエネルギーの大きい電磁波で, 这過力は最も強く，我々の身体等は平気で透過致しま す.フイントープのコバルト 60 から出る $\gamma$ 線は 1 糎 の鉛板で覆っても半分になる程度で, 普通 400 キュリ 一程度の照射装置では 鉛の厚さ 20 糎位のボンべに収 容されております。電磁波さいうのは形も重さむない 電気的土ネルギーと磁気的エネルギーを含む一つの波 動で光も，ラジオも，レントゲン線む皆電磁波です。 キュリーとは放射性物質そのものの多い少いを表わす もので後程申し上げます。
さて次にこれ等の放射線を測定するにはどんな浿定 器が用いられているかと申しますと，皆さん御承知の ガイガー：ミュラー計数管しいうのがあります：これ は独逸の物理学者"ハンスガイガー゙と"ウオルター ミュラー"の三人の名前をとったもので, G.M.管とも いかれております，大さは種種ありますが，普通直径 1 糎長さ 5 糎の位の金属の筒で其の先に雲母が張って あり，中にフルゴンガスとフルコールを入れ；0.02粍 位のタングステン線を中心に張って，これを内極（陽 極）と呼び，外側の金属筒は真鍮又はアルミニューム 等から出来ておりこれを外極（陰極）といって，両極 間に約 $1500 \mathrm{~V}$ の電圧をかけておきます。

今放射線が入ってくると中のガスを電離して，陽極 と陰極間に放電を起し電流を流します。この電流を増 幅器で增幅しネオンランプを点隇させたり, 又拡声器 で音を出すようにしてあります。

次にシンチレーション計数管というのがあり亦と が，これはシンチレーターと呼ばれる䖝光体と其の光 を受けて電気的パルスに变換增幅する增幅器から出来 ており，熄光体の発する光子の数が入射粒子に比例し て非常に感度がよくて䖝光物質としては沃化ナトリゥ ム,タングステン酸カドミゥム等が用いられておりま す. 其の他に散乱線測定用として，放射線に曝射した 時間丈の積算量がミリレントゲンで判る電離作用を利 用した小型万年筆状直䛃式ポケットチエンバー，又注 障害予防に胸等につけてフィルムの黑化度から曝射線 量を測定するフィルムバッヂ等があります。

それでは前述のミリレントゲンとはどんな単位かと 申しますと，乾燥した空気 1 立方糎 $\left(0^{\circ} \mathrm{C}, 1\right.$ 気在)に レントゲン線を照射して発生した正負のイオンにより 1静電単位の電気量が運ばれるような線量を1レントゲ ンといって，千分の一をミリレントゲンといいます。

簡単に申しますと普通レントゲンの直接胸部撮影で は, 30〜300 ミリレントゲン位です。

又コバルト 60 等の放射性物質そのものの多い少い を表すのに,キュリーといら単位を使用していますが， これは放射線源そのものの放射能の量を意味し，放射 線量を示するのではありません．1キュリーとは放射 性元素が 1 秒間に 370 億個の原子を崩壊する時, その 物質の放射能の強さを 1 キュリーといって，これはラ ジウム 1 瓦が 1 秒間に崩磅する放射能の強さと同じで ありをす。

又別に，カウントという言葉がありますが，これは G. M. 管に入った粒子に依り決められるもので，1ケ 入れば1カウントを示しますが，どんな種類の放射線 が入って来た亦は解りません，従って以上のレントゲ ソキュリー; カカウントは其の測定している意味も方 
法も異りますからこの三者は一定条件の下でなけれ ば関係づける事は出来ません。

さてアイントープの利用には，二通りの方法があっ て，其の一つは放射線の線源として用いる事，他の一 つはアイントーブが安定な同じ種類の元素と同じ行動 をさせて放射能㹸より所在が判る事を利用; 即らトレ ーサーとして利用する事であります。

線源として用いる場合は医療方面に於ては，ラジウ ムやエックス線 深部治療装置に代りコバルト60が用 いられるようになった，その理由としては，ラジウム に比較すると価格が低廉である事，放射線量が多い事 で，即ちラジウムは 1 ミリキュリー1,500円，コバル 卜 60 は 6 丹，又線量の方は $1 \neq$ キーで 1 米の距蜼 で 1 時間に付ラジウムは 0.84 R.h.m. .コバルトは 1.35 R. h.m. 又エックス線に比べると線質が硬く 深部特性が良く $3 \mathrm{MeV}$.の超高圧ェックス線に匹敵す る放射線が大量に照射出来，取扱が非常に簡単であり ます. 然し寿命が短いのが欠点で, 即ち半減期が 5.3 年 です.

半滅期とは放射線の寿命即ち隇り方を表すもので， 方谢性の元素は日々其の放射線量を減少していますか ら初めの半分にになる期限を半減期といいます。

其の他医療用として利用されてるアイントープとし ては，放射性沃度 ( $\left.\mathbf{I}^{131}\right)$ 放射性燐（ $\left.\mathrm{P}^{32}\right)$ 放射性ナト リゥム $\left(\mathrm{Na}^{24}\right)$ 等があり，放射性沃度は $\gamma$ 線を放出し て半隇期が 8 日で，沃度が甲状腺に特に集る性質を利 用して甲状腺の悪性腫㢞や機能診断の目的に使われ， 又放射性橉は $\beta$ 線を出して半減期が 14 日，特殊な方

アセテート 熔けるように燃え醋酸の真いを発す る.

ナイロン 火を近づけると熔け，火の中では熔け つつ燃える. 冷えるとかたい球となる。

ビニロン 火を近づけるとちぢみ，そのご熔け， 冷えるとかたくなる。

年,
}

法で谱紙に浸みこませて外へ漏れないようにして必要 な時間丈アザに胋るとこの $\boldsymbol{\beta}$ 線は深く行かないで表面 のアザの所丈エネルギーが働いてアザの治療に用いら れております。

放射性ナトリゥム注 $\beta$ 線を出して半減期が 15 洔間 で，薬品にまぜて身体に入れてやり，これを G，M.管 で測定して所在を確め所謂トレーサーとして使用され ます。.

最後にアイソトプに関する障害について簡単に述べ ますと， $\alpha$ 線， $\beta$ 線，は何机も荷電粒子であって物質 を通る時は電離を起します，又X線， $\gamma$ 線，中性子線 は荷電粒子でなく電磁波でありますが何れも二次的な 作用で電離を起して生物体がこれ等の放射線を受什る こ組織が直接電離されたり，又は周囲の電離を介して 間接的に化学变化を受ける結果細胞に变化が起り, 白 血球の減小, 脱毛, 貧血, 墨性の腫瘍，白血病等の放 射線の障害を起します。

それでは我々人体に対する放射線の許容量はどれ丈 であるかと申しますと，1950年の国際放射線学会に於 て最大許容量を 1 週間当り 300 ミリレントダンと決め られましたが，これでは多過ぎるるいう声も盛てにな り昨年の国際放射線防禦委員会では，更に少くして 1 週間当り 100 ミリレントゲンと決めてありますがなほ 減少の方向に進えで㧍ります。然し何れにしても我々 は外部から来る直接の放射線は勿論の事，空気や食べ 物を通して来る放射性物質に対しても充分に気をつけ なければなりません。

（13頁よりつがく）

500ccを流すことは危険であるので，自ら限界がある。 大体200〜250ccの間で流すのが能率を高め安全で，こ れが大体限界ではないかと思う。

次は透析装置を並列又は直列に連結した場合である が，第28図の程度の違いがあるにすぎない．

透析する際の血液あるいは灌流液の温度であるが， 温度は38 C の場合透析能率はよいのである(第29図). 人工冬眠というのがあって，心蔵手術とが脳の手術な どに震々身体を冷却するがこういうときに身体を冷や すと透析能率は低くなってくる．や梳り一定の体温程

度の温度がないといけない。

\begin{tabular}{|c|c|c|c|c|c|}
\hline$x$ & & $\times$ & & $x$ & \\
\hline & $x$ & & $x$ & & $x$ \\
\hline$x$ & & $x$ & & $x$ & \\
\hline
\end{tabular}

